\title{
MODEL PENGEMBANGAN DAN IMPLEMENTASI KURIKULUM PAI DI SMP MUHAMMADIYAH 1 DEPOK YOGYAKARTA
}

\author{
Arham Junaidi Firman \\ UIN Sunan Kalijaga Yogyakarta, Indonesia \\ arhamjf@yahoo.com
}

\begin{abstract}
This study aims to examine specifically the development and implementation of the curriculum conducted by Muhammadiyah 1 Junior High School Depok Yogyakarta. The research method used was qualitative research with the locus of Muhammadiyah 1 Junior High School Depok Yogyakarta. The subject of data collection was the deputy head of the curriculum and Islamic religious education teachers who carried out through empirical observation, in-depth interviews and documentation. Data analysis was performed by data reduction, display and verification. The results showed that, namely: First, the development of Islamic religious education curriculum in Muhammadiyah 1 Junior High School Depok Yogyakarta (MUSADE) using the basis as a reference and in accordance with the steps of its development and has involved various parties in the curriculum development process. In addition, curriculum development also emphasizes the strengthening of character education as reflected in intracuricular, cocurricular and extracurricular activities. Second, the implementation of the curriculum at Muhammadiyah 1 Junior High School Depok Yogyakarta (MUSADE) can be seen from Islamic religious education teachers who have prepared themselves as well as possible with the teacher's understanding of the curriculum. The implementation of the curriculum includes three aspects, namely planning the learning process, implementing the learning process and evaluating the learning process, although in its implementation there are still obstacles.
\end{abstract}

Keywords: Development, Implementation, Curriculum

Abstrak: Penelitian ini bertujuan untuk mengkaji secara spesifik pengembangan dan implementasi kurikulum yang dilakukan oleh SMP Muhammadiyah 1 Depok Yogyakarta. Metode penelitian yang digunakan adalah penelitian kualitatif dengan lokus SMP Muhammadiyah 1 Depok Yogyakarta. Subyek pengumpulan data adalah waka kurikulum dan guru pendidikan agama Islam yang dilakukan melalui observasi empirik, wawancara mendalam dan dokumentasi. Analisis data dilakukan dengan reduksi, display dan verifikasi data. Hasil penelitian menunjukkan bahwa, yaitu: Pertama, Pengembangan kurikulum pendidikan agama Islam di SMP Muhammadiyah 1 Depok (MUSADE) menggunakan dasar yang dijadikan sebagai acuan dan telah sesuai dengan langkah-langkah pengembangannya serta telah melibatkan berbagai pihak dalam proses pengembangan kurikulum. Selain itu, pengembangan kurikulum juga menekankan pada penguatan pendidikan karakter yang tercermin dari kegiatan intrakurikuler, kokurikuler dan ekstrakurikuler. Kedua, Implementasi kurikulum di SMP Muhammadiyah 1 Depok (MUSADE) bisa dilihat dari guru pendidikan agama Islam yang telah mempersiapkan diri dengan sebaik-baiknya, sehingga memiliki pemahaman secara seksama terhadap kurikulum. Implementasi kurikulum mencakup tiga aspek, yaitu perencanaan proses pembelajaran, pelaksanaan proses pembelajaran dan penilaian proses pembelajaran, meskipun dalam implementasinya masih ditemukan hambatan-hambatan.

Kata Kunci: Pengembangan, Implementasi, Kurikulum 


\section{A. PENDAHULUAN}

Proses pendidikan Islam telah berlangsung sepanjang sejarah dan berkembang sejalan dengan perkembangan agama Islam dan sosial budaya dalam masyarakat. Peningkatan mutu pendidikan agama Islam bukanlah suatu usaha sederhana, karena banyak aspek yang terkait dengan mutu pendidikan tersebut. ${ }^{1}$ Berbagai cara dilakukan untuk meningkatkan mutu pendidikan agama Islam, salah satunya melalui penataan kurikulum. Kualitas pembelajaran agama Islam sangat dipengaruhi oleh bagaimana lembaga pendidikan dapat mengembangkan kurikulum berdasarkan tuntutan masyarakat sehingga dapat menjadikan peserta didik sebagai penerus umat yang unggul. Kurikulum merupakan salah satu perangkat penting dalam pendidikan. Selain itu, kurikulum juga mempunyai posisi sentral dalam mewujudkan tujuan dan sasaran pendidikan yang dicita-citakan. Kurikulum sendiri merupakan seperangkat rencana dan pengaturan mengenai tujuan, isi dan bahan pembelajaran untuk mencapai tujuan pendidikan tertentu. ${ }^{2}$

Arah dan tujuan kurikulum pendidikan akan senantiasa mengalami pergeseran dan perubahan seiring dengan dinamika perubahan sosial yang disebabkan oleh berbagai faktor, baik internal maupun eksternal. Karena sifatnya yang dinamis dalam menyikapi perubahan, kurikulum mutlak harus bersifat fleksibel dan futuristik. Ketimpangan-ketimpangan dalam disain kurikulum karena kurang respon terhadap perubahan sosial boleh jadi berkonsekuensi kepada lahirnya output pendidikan yang "gagap" dalam beradaptasi dengan kondisi sosial yang dimaksud. ${ }^{3}$

Atas dasar pertimbangan ini, maka pengembangan dan implementasi kurikulum menjadi salah satu aspek penting yang harus dilakukan dalam dunia pendidikan. Pengembangan dan implementasi kurikulum adalah terjemahan kurikulum dokumen menjadi kurikulum sebagai aktivitas atau kenyataan. Pengembangan dan implementasi kurikulum memiliki posisi yang sangat menentukan bagi keberhasilan kurikulum sebagai rencana tertulis. Kegiatan

1 Mansur \& Mahfud Junaidi, Rekonstruksi Sejarah Pendidikan Islam di Indonesia, (Jakarta: Departemen Agama RI, 2005), hlm. 7.

2 Yudrik Jahya, Pandangan Pelaksanaan Kurikulum Raudhatul Athfal, (Jakarta: Departemen Agama RI, 2005), hlm. 4.

${ }^{3}$ Syamsul Bahri, "Pengembangan Kurikulum Dasar dan Tujuannya", dalam Jurnal Ilmiah Islam Futura, Vol. XI, No. 1, 2011, hlm. 16. 
pengembangan dan implementasi kurikulum hampir seluruhnya tergantung pada kreativitas, kecakapan, kesungguhan dan ketekunan guru.

Banyak hal yang harus diperhatikan dalam pengembangan dan implementasi kurikulum, mulai dari pemahaman teori dan konsep kurikulum, asas-asas kurikulum, macam-macam model konsep kurikulum, anatomi dan desain kurikulum, landasan-landasan pengembangan kurikulum dan lain-lain yang berkaitan dengan proses pengembangan serta implementasi kurikulum. ${ }^{4}$ Selain itu, pengembangan dan implementasi kurikulum yang dilaksanakan oleh berbagai sekolah juga merupakan wujud dari aktualisasi desentralisasi pendidikan dan akan berdampak terhadap mutu pendidikan di Indonesia.

Pada era desentralisasi pendidikan, terjadi berbagai variasi dan jenis kurikulum pada setiap satuan pendidikan karena masing-masing mengembangkan kurikulum, sehingga antara satu sama lain boleh jadi berbeda. Namun demikian, perbedaan ini tetap berpedoman pada Standar Nasional Pendidikan sehingga kemasan kurikulum yang berbeda-beda ini pada akhirnya akan bermuara pada visi, misi dan tujuan yang sama-sama diinginkan. ${ }^{5}$

Dalam Undang-Undang No. 20 tahun 2003 tentang Sistem Pendidikan Nasional pasal 36 ayat 1 disebutkan bahwa "Pengembangan kurikulum dilakukan dengan mengacu Standar Nasional Pendidikan [SNP] untuk mewujudkan tujuan pendidkan nasional." Pada Pasal 3 dijelaskan bahwa tujuan pendidikan nasional untuk "pemberdayaan potensi peserta didik agar menjadi manusia yang beriman dan bertakwa kepada Tuhan Yang Maha Esa, berakhlak mulia, (memiliki nilai dan sikap), sehat berilmu, cakap, kreatif (berilmu pengetahuan), mandiri, dan menjadi warga negara yang demokratis dan bertanggungjawab (kecakapan psikomotorik)." 6

Oleh karena itu, fokus penelitian ini adalah bagaimana pengembangan dan implementasi kurikulum sebagai salah satu aspek penting untuk meningkatkan mutu pendidikan. Jenis penelitian yang digunakan adalah penelitian kualitatif

${ }^{4}$ Loc.cit.

${ }^{5}$ Siti Zulfatun Khasanah \& Zainal Arifin, "Implementasi Pengembangan Kurikulum di SMP Muhammadiyah Boarding School (MBS) Yogyakarta", dalam Tadris: Jurnal Pendidikan Islam, Vol. 12, No. 1, 2017, hlm. 81.

${ }^{6}$ Depdiknas, Undang-Undang Nomor 20 Tahun 2003 Tentang Sistem Pendidikan Nasional, (Jakarta: Depdiknas, 2003), hlm. 4. 
dengan tema Model Pengembangan dan Implementasi Kurikulum PAI di SMP Muhammadiyah 1 Depok, Sleman, Yogyakarta. Teknik pengumpulan data yang digunakan dalam penelitian ini, yaitu observasi, wawancara dan dokumentasi. Analisis data dalam penelitian ini dilakukan dengan reduksi data, display data dan verifikasi data.

Berdasarkan hasil observasi empirik di lapangan menunjukkan SMP Muhammadiyah 1 Depok Yogyakarta (MUSADE) merupakan salah satu sekolah yang melakukan pengembangan kurikulum dan mengimplementasikannya dalam rangka mencapai visi, misi dan tujuan sekolah. Pada tahun 2011, SMP Muhammadiyah 1 Depok (MUSADE) menggunakan Al-Islam Kemuhammadiyahan Bahasa Arab dan Bahasa Inggris (ISMUBA) sebagai bentuk desentralisasi pendidikan dalam kurikulum pendidikan agama Islam. Oleh karena itu, hal tersebut memiliki daya tarik dan menjadi dasar bagi peneliti untuk melakukan penelitian. Adapun pertanyaan penelitian yang ingin dijawab, yaitu: Pertama, bagaimana pengembangan kurikulum PAI di SMP Muhammadiyah 1 Depok; Kedua, bagaimana implementasi kurikulum PAI di SMP Muhammadiyah 1 Depok.

\section{B. PENGEMBANGAN DAN IMPLEMENTASI KURIKULUM}

\section{Pengembangan Kurikulum}

Istilah pengembangan mengarah kepada suatu kegiatan yang menghasilkan hal atau cara baru dengan memberikan penilaian dan penyempurnaan terhadap kegiatan yang dilakukan. Hal ini juga berlaku dalam pengembangan kurikulum pendidikan, karena pengembangan kurikulum berkaitan langsung dengan penyusunan kurikulum itu sendiri dan pelaksanaannya pada satuan pendidikan disertani dengan evaluasi dengan intensif. ${ }^{7}$

Pengembangan kurikulum merupakan sebuah proses perencanaan kurikulum untuk menghasilkan kurikulum yang luas dan spesifik. Proses pengembangan kurikulum tersebut berhubungan dengan seleksi dan pengorganisasian berbagai komponen situasi belajar-mengajar, antara lain penetapan jadwal pengorganisasian kurikulum dan spesifikasi tujuan yang disarankan, mata pelajaran, kegiatan, sumber hlm. 34

${ }^{7}$ Heri Gunawan, Kurikulum dan Pembelajaran Pendidikan Agama Islam, (Bandung: Alfabeta, 2013), 
dan alat pengukur pengembangan kurikulum yang mengacu pada kreasi sumbersumber unit, rencana unit, dan garis pelajaran kurikulum ganda lainnya, untuk memudahkan proses belajar-mengajar. ${ }^{8}$

Dalam pendapat lain, pengembangan kurikulum diartikan sebagai suatu kegiatan yang menghasilkan kurikulum, atau proses yang mengaitkan satu komponen dengan komponen lainnya untuk menghasilkan suatu kurikulum yang baik, atau kegiatan penyusunan, implementasi dan evaluasi serta kegiatan perbaikan dan penyempurnaan kurikulum. ${ }^{9}$

Pengembangan kurikulum menggunakan prinsip-prinsip yang telah berkembang dalam kehidupan sehari-hari atau justru menciptakan prinsip-prinsip baru. Oleh karena itu, dalam pengembangan kurikulum di lembaga pendidikan sangat dimungkinkan untuk menggunakan prinsip yang berbeda dari kurikulum yang digunakan sdi lembaga pendidikan lain, sehingga akan ada banyak prinsip yang digunakan dalam pengembangan kurikulum.10

Sukmadinata dalam Shofiyah menyatakan prinsip pengembangan kurikulum yang terbagi menjadi dua jenis, yaitu prinsip umum dan prinsip pesifik. Prinsip umum pengembangan kurikulum adalah relevansi, fleksibilitas, kontinuitas, kepraktisan dan efektivitas. Prinsip-prinsip ini adalah landasan yang kuat untuk mewujudkan kurikulum berdasarkan kebutuhan peserta didik, guru, dan masyarakat. Prinsip khusus pengembangan kurikulum adalah berkaitan dengan tujuan pendidikan, prinsip yang berkaitan dengan pemilihan konten pendidikan, prinsip yang berkaitan dengan pemilihan proses belajar mengajar, prinsip yang berkaitan dengan pemilihan media dan alat belajar, dan prinsip yang berkaitan dengan pemilihan kegiatan penilaian. ${ }^{11}$

8 Oemar Hamalik, Dasar-Dasar Pengembangan Kurikulum, (Bandung: Remaja Rosdakarya, 2008), hlm. 183-184.

${ }_{9}^{9}$ Muhaimin, Pengembangan Kurikulum Pendidikan Agama Islam di Sekolah, (Jakarta: Raja Grafindo Persada, 2007), hlm. 10.

${ }^{10}$ Fitroh, "Pengembangan Kurikulum Berbasis Kompetensi dan Strategi Pencapaian", dalam Studi Informatika: Jurnal Sistem Informasi, Vol. 4, No. 2, 2011, hlm. 2.

11 Shofiyah, "Prinsip-Prinsip Pengembangan Kurikulum dalam Upaya Meningkatkan Kualitas Pembelajaran", dalam Edureligia: Jurnal Pendidikan Agama Islam, Vol. 2, No. 2, 2018, hlm. 128. 


\section{Implementasi Kurikulum}

Implementasi mengarah kepada pelaksanaan atau penerapan. Implementasi adalah suatu proses penerapan, ide, konsep, kebijakan atau inovasi dalam suatu tindakan praktis seingga memberikan dampak, baik berupa perubahan pengetahsuan, keterampilan, maupun nilai dan sikap. Implementasi kurikulum dapat diartikan sebagai aktualisasi kurikulum tertulis dalam bentuk pembelajaran. ${ }^{12}$

Implementasi kurikulum merupakan suatu kegiatan yang bertujuan untuk mewujudkan atau melaksanakan kurikulum (dalam arti rencana tertulis) ke dalam bentuk nyata di kelas, yaitu terjadinya proses transmisi dan transformasi segenap pengalaman belajar kepada peserta didik. Beberapa istilah yang bisa disepadankan dengan istilah implementasi kurikulum yaitu pembelajaran.

Implementasi kurikulum memiliki posisi yang sangat menentukan bagi keberhasilan kurikulum sebagai rencana tertulis. Hasan dalam Suyatmini mengatakan "...jika kurikulum dalam bentuk rencana tertulis dilaksanakan maka kurikulum dalam bentuk proses adalah realisasi atau implementasi dari kurikulum sebagai rencana tertulis". ${ }^{13}$ Bisa jadi, dua orang guru yang sama-sama mengimplementasikan sebuah kurikulum (misal, kurikulum mata pelajaran akuntansi) akan diterima atau dikuasai anak secara berbeda bukan karena isi atau aspek-aspek kurikulumnya yang berbeda, tetapi lebih disebabkan perbedaan dalam implementasi kurikulum yang diupayakan guru tersebut.

Implementasi kurikulum merupakan terjemahan kurikulum dokumen menjadi kurikulum sebagai aktivitas atau kenyataan. Aspek penting yang perlu diperhatikan dalam implementasi kurikulum antara lain adalah (1) aspek makro pengembangan kurikulum (kondisi masyarakat, politik, sosial, budaya, ekonomi, teknologi); (2) aspek materi dan prosedur pengembangan kurikulum sebagai ide; (3) aspek materi dan prosedur pengembangan kurikulum sebagai dokumen; (4) aspek materi dan

12 Kunandar, Guru Profesional Implementasi Kurikulum Tingkat Satuan Pendidikan (KTSP) dan Sukses dalam Sertifikasi Guru, (Jakarta: Raja Grafindo Persada, 2007), hlm. 211.

13 Suyatmini, "Implementasi Kurikulum 2013 pada Pelaksanaan Pembelajaran Akuntansi di Sekolah Menengah Kejuruan", dalam Jurnal Pendidikan Ilmu Sosial, Vol. 27, No. 1, 2017, hlm. 60-61. 
implementasi diwujudkan dalam kegiatan belajar dan mengajar menjadikan peserta didik lebih kompeten; dan (5) aspek materi dan prosedur evaluasi hasil belajar. ${ }^{14}$

\section{PENGEMBANGAN KURIKULUM PAI DI SMP MUHAMMADIYAH 1 DEPOK (MUSADE)}

Pengembangan kurikulum pendidikan agama Islam merupakan pengembangan komponen-komponen kurikulum pendidikan agama Islam yang membentuk sistem kurikulum itu sendiri, seperti: tujuan, bahan, metode, peserta didik, pendidik, media, lingkungan sumber belajar dan lain-lain.15 Dalam mengembangkan suatu kurikulum banyak pihak yang turut berpartisipasi tentunya, diantaranya: administrator pendidikan, ahli pendidikan, ahli kurikulum, ahli bidang ilmu pengetahuan, guru-guru dan orang tua murid serta tokoh-tokoh masyarakat. ${ }^{16}$

Dalam merencanakan konsep pengembangan kurikulum PAI di SMP Muhammadiyah 1 Depok, terdapat dasar yang dijadikan sebagai acuan dalam pengembangannya, yaitu mengacu kepada Kurikulum Kemendikbud dan Kurikulum dari Majelis Pendidikan Dasar dan Menengah (Dikdasmen). Adapun langkah-langkah pengembangan kurikulum di SMP Muhammadiyah 1 Depok, yaitu: Pertama, Melibatkan warga sekolah, seperti Guru, Komite Sekolah, Masyarakat dan Majelis Dikdasmen (Pendidikan Dasar dan Menengah). Kedua, Melakukan uji publik terhadap materi di Sekolah. Ketiga, Pelaksanaan. ${ }^{17}$

Telaah terhadap hasil wawancara di atas menunjukkan bahwa SMP Muhammadiyah 1 Depok dalam mengembangkan kurikulum pendidikan agama Islam telah sesuai dengan langkah-langkah pengembangannya dan telah melibatkan berbagai pihak dalam proses pengembangan kurikulum, yaitu Guru, Komite Sekolah, Masyarakat dan Majelis Dikdasmen (Pendidikan Dasar dan Menengah).

Kurikulum akan selalu berkembang, tidak mungkin akan stagnan, karena masyarakat sebagai kelompok manusia yang tumbuhkembang. Perkembangan

14 Syaiful Sagala, "Pengembangan dan Implementasi Kurikulum Penting Untuk Meningkatkan Kualitas Pembelajaran", dalam Digital Repository Universitas Negeri Medan, 2016, hlm. 128.

${ }^{15}$ Abdullah Idi, Pengembangan Kurikulum dan Praktik, (Yogyakarta: Ar-Ruzz Media, 2007), hlm. 186.

16 Nana Syaodih Sukmadinata, Pengembangan Kurikulum Teori dan Praktik, (Bandung: Remaja Rosdakarya, 2013), hlm. 155. 2018.

17 Wawancara dengan Abidin Fuadi, (Waka Kurikulum SMP Muhammadiyah 1 Depok), Mei 
kurikulum akan mengikuti perkembangan zaman dan masyarakat, karena masyarakat menjadi sumber pengetahuan dan pengalaman. Pengetahuan dan pengalaman yang didapat dari masyarakat akan digodok, diramu, dan diracik serta mengkristal menjadi suatu kurikulum.

Oleh karena itu, pengembangan kurikulum pendidikan agama Islam harus memperhatikan asas-asas, prinsip-prinsip, organisasi dan desain kurikulum yang ada, sehingga pengembanganya dapat berjalan dengan baik, berjalan di jalur yang direncanakan, dan mencapai tujuan pendidikan dengan baik. Pengembangan bukan hal yang mudah, karena itu dalam pengembangannya harus memperhatikan hal-hal komprehensif yang menjadi pemandu, pembimbing pengembangan kurikulum pendidikan agama Islam. ${ }^{18}$

Berdasarkan hal tersebut, maka bentuk pengembangan kurikulum yang dilakukan oleh SMP Muhammadiyah 1 Depok adalah dengan mengintegrasikan kurikulum dari Kemendikbud dan Majelis Dikdasmen. Kurikulum dari Kemendikbud berupa kurikulum KTSP dan K-13 untuk mata pelajaran umum, sedangkan kurikulum dari Majelis Dikdasmen, yaitu kurikulum ISMUBA (Al-Islam Kemuhammadiyahan Bahasa Arab) untuk mata pelajaran agama Islam yang dibuat dan berlakukan berdasarkan SK Majelis Dikdasmen Nomor 98 Tahun 2017. Berdasarkan arahan dari Dinas Pendidikan Kabupaten Sleman tahun ajaran 2017/2018, maka untuk kelas 8 dan 9 menggunakan kurikulum KTSP dan kelas 7 menggunakan kurikulum 2013, sedangkan ISMUBA diterapkan untuk semuanya. ${ }^{19}$

Dapat dipahami bahwa proses pengembangan kurikulum pendidikan agama Islam ini berhubungan dengan seleksi dan pengorganisasian berbagai komponen situasi belajar-mengajar, hal ini sama dengan pengembangan kurikulum pendidikan agama Islam di SMP Muhammadiyah 1 Depok yang bertujuan untuk membentuk peserta didik berkarakter melalui integrasi kurikulum dari Kemendikbud dengan kurikulum Dikdasmen sehingga terjadi penyelarasan pendidikan agama dengan

18 Rosichin Mansur, "Pengembangan Kurikulum Pendidikan Agama Islam Multikultural", dalam Jurnal Kependidikan dan Keislaman FAI Unismea, Vol. 10, No. 2, 2016, hlm. 2.

${ }_{19}$ Wawancara dengan Abidin Fuadi, (Waka Kurikulum SMP Muhammadiyah 1 Depok), Mei 2018. 
pendidikan umum. Adapun struktur kurikulum ISMUBA berdasarkan hasil dokumentasi yang dilakukan di SMP Muhammadiyah 1 Depok, yaitu:

Tabel 1

Struktur Kurikulum ISMUBA

\begin{tabular}{|c|c|c|c|c|c|c|c|}
\hline \multirow{3}{*}{ No } & \multirow{3}{*}{ Mata Pelajaran } & \multicolumn{6}{|c|}{$\begin{array}{l}\text { Kelas, Semester dan } \\
\text { Alokasi Waktu }\end{array}$} \\
\hline & & \multicolumn{2}{|c|}{ VII } & \multicolumn{2}{|c|}{ VIII } & \multicolumn{2}{|c|}{ IX } \\
\hline & & 1 & 2 & 1 & 2 & 1 & \\
\hline 1. & Al-Qur'an (Tahsin Tilawah, Tahfidz) & 3 & 3 & 3 & 3 & 3 & 3 \\
\hline 2. & Pendidikan Aqidah Akhlak & 2 & 2 & 2 & 2 & 2 & 2 \\
\hline 3. & Pendidikan Fikih & 3 & 3 & 3 & 3 & 3 & 3 \\
\hline 4. & Pendidikan Tarikh & 1 & 1 & 1 & 1 & 1 & 1 \\
\hline 5. & Pendidikan Kemuhammadiyahan & 1 & 1 & 1 & 1 & 1 & 1 \\
\hline 6. & Pendidikan Bahasa Arab & 2 & 2 & 2 & 2 & 2 & 2 \\
\hline & Jumlah Jam & 12 & 12 & 12 & 12 & 12 & 12 \\
\hline
\end{tabular}

Sumber: Buku ISMUBA SMP Muhammadiyah 1 Depok.

Analisis dokumentasi di atas mengindikasikan bahwa pengembangan kurikulum agama Islam yang dilakukan oleh SMP Muhammadiyah 1 Depok terwujud dalam kurikulum ISMUBA yang mengintegrasikan ilmu umum dengan ilmu agama. Adapun aspek yang dikembangkan dalam kurikulum ISMUBA ini, yaitu struktur kurikulum, standar kompetensi lulusan, standar isi, standar proses dan standar penilaian berdasarkan Surat Keputusan Majelis Pendidikan Dasar dan Menengah Pimpinan Pusat Muhammadiyah Nomor 98 Tahun 2017.

Kurikulum ISMUBA merupakan muatan pendidikan pokok dalam sistem Pendidikan Muhammadiyah yang memiliki fungsi untuk membina dan mengantarkan peserta didik menjadi insan yang beriman dan bertakwa kepada Allah, berakhlak mulia, mengamalkan ajaran Islam dalam kehidupan sehari-hari sesuai dengan tuntunan Al-qur'an dan As-sunnah. ISMUBA merupakan pembelajaran yang harus ditekuni oleh setiap pelajar Muhammadiyah. Kurikulum ini terdiri dari, yaitu Akidah, Akhlak, Ibadah, Tarikh, Bahasa Arab dan Al-qur'an Hadits serta Kemuhammadiyahan yang merupakan mata pelajaran khusus bagi peserta didik di sekolah Muhammadiyah untuk mengatasi dan menjawab kehausan peserta didik dalam bidang keagamaan. ${ }^{20}$ Berdasarkan Surat Keputusan Majelis

${ }^{20}$ Lukman Ismail \& Risfaisal, "Eksistensi Gerakan Muhammadiyah dalam Pendidikan di Era Modernisasi", dalam Jurnal Equilibrium Pendidikan Sosiologi, Vol. V, No. 2, 2017, hlm. 181. 
Pendidikan Dasar dan Menengah Pimpinan Pusat Muhammadiyah Nomor 98 Tahun 2017, maka Kurikulum Al-Islam, Kemuhammadiyahan dan Bahasa Arab (ISMUBA) yang dimaksud adalah: ${ }^{21}$

1. Standar Kompetensi Lulusan mencakup capaian minimal dari pada setiap jenjang pendidikan untuk mata pelajaran pendidikan Al-Islam, Kemuhammadiyahan dan Bahasa Arab. SKL ini terdiri dari dimensi sikap, seperti beriman dan bertakwa, berakhlak karimah. Dimensi pengetahuan, seperti memiliki pengetahuan faktual, konseptual, prosedural, metakognitif dan suprarasional pada tingkat teknis dan spesifik sederhana. Dimensi keterampilan, seperti memiliki keterampilan berfikir dan bertindak kreatif, produktif, kritis, mandiri, kolaboratif dan komunikatif.

2. Standar Isi mencakup ruang lingkup materi dan tingkat kompetensi untuk mencapai kompetensi lulusan pada jenjang dan jenis pendidikan tertentu. Standar Isi disesuaikan dengan substansi tujuan pendidikan nasional dalam domain sikap spiritual dan sikap sosial, pengetahuan dan keterampilan. Standar Isi terdiri dari Kompetensi Inti (KI) dan Kompetensi Dasar (KD).

3. Standar Proses pendidikan di SMP Muhammadiyah dilaksanakan secara integratif-holistik atau dikenal juga dengan sekolah umum yang mengintegrasikan ilmu-ilmu agama Islam. Dalam sistem pendidikan integratifholistik, keberadaan ISMUBA merupakan mata pelajaran yang berdiri sendiri, akan tetapi dalam proses pendidikannya terintegrasi dengan mata pelajaran lain termasuk seluruh kegiatan sekolah. Standar Proses mencakup tentang prinsip pembelajaran, perencanaan pembelajaran seperti Silabus dan RPP, pelaksanaan pembelajaran, penilaian proses dan hasil pembelajaran dan pengawasan proses pembelajaran.

4. Standar Penilaian mencakup tentang ruang lingkup panduan penilaian, yang meliputi prinsip-prinsip penilaian ISMUBA, penilaian oleh guru ISMUBA dan Mejelis Dikdasmen, penilaian sikap, pengetahuan dan keterampilan, 
pengolahan hasil penilaian, pemanfaatan dan tindak lanjut hasil penilaian, serta format dan petunjuk pengisian rapor.

Selain itu, pengembangan kurikulum pendidikan agama Islam di SMP Muhammadiyah 1 Depok juga menekankan pada penguatan pendidikan karakter. Penguatan pendidikan karakter ini tercermin dari kegiatan intrakurikuler, kokurikuler dan ekstrakurikuler di SMP Muhammadiyah 1 Depok yang selalu diintegrasikan dengan kegiatan keagamaan. Misalnya, kegiatan tahfiz, hafalan juz ama dan surat-surat pilihan, pada setiap hari Jum'at selalu mengadakan kegiatan PPK (Penguatan Pendidikan Karakter) dari jam 07.00-07.30 WIB.22 Adapun rincian kegiatan PPK berdasarkan hasil wawancara, observasi yaitu: Pertama, Jum'at minggu pertama dinamakan Jum'at Olahraga dengan kegiatan Senam, Sepeda Santai, Sekolah Sehat dan lain-lain. Kedua, Jum'at minggu kedua dinamakan Jum'at Gizi dengan kegiatan makan bersama di Sekolah. Ketiga, Jum'at minggu ketiga dinamakan Jum'at Kerja Bakti dengan kegiatan bersih-bersih lingkungan sekolah. Keempat, Jum'at minggu keempat dinamakan Jum'at Budaya dengan kegiatan peserta didik dituntut untuk mengekspresikan seni yang ada dalam dirinya, seperti berpidato. ${ }^{23}$

Sementara itu, sudah menjadi tradisi bahwa setiap kegiatan tidak lepas dari berbagai macam faktor yang mempengaruhi keberhasilannya, yaitu: adanya faktor pendukung dan penghambat. Berdasarkan hasil wawancara dan observasi yang dilakukan menunjukkan bahwa pelaksanaan pengembangan kurikulum pendidikan agama Islam di SMP Muhammadiyah 1 Depok dipengaruhi oleh beberapa faktor, yaitu: 1) faktor pendukung, seperti perkembangan ilmu pengetahuan dan teknologi, kebijakan-kebijakan yang dikeluarkan oleh dinas pendidikan dan dikdasmen, dan 2) faktor penghambat, seperti kreativitas guru dalam mengembangkan kurikulum dan peserta didik. ${ }^{24}$

22 Observasi dan Dokumentasi Kegiatan Penguatan Pendidikan Karakter di SMP Muhammadiyah 1 Depok, Juni 2018.

${ }^{23}$ Wawancara dengan Abdullah Mukti, (Kepala SMP Muhammadiyah 1 Depok), Juni 2018.

${ }^{24}$ Observasi dan Wawancara dengan Abdullah Mukti, (Kepala SMP Muhammadiyah 1 Depok), Mei 2018. 


\section{IMPLEMENTASI KURIKULUM PAI DI SMP MUHAMMADIYAH 1 DEPOK (MUSADE)}

Implementasi kurikulum memiliki sejumlah komponen dan aspek-aspek, faktor, dan strategi yang perlu ditata dan dikelola secara baik sehingga tujuan kurikulum dapat dicapai. Implementasi kurikulum merupakan salah satu bagian penting dari manajemen kurikulum. Implementasi kurikulum memerlukan suatu proses manajemen yang kuat dan baik. Implementasi kurikulum dapat dilihat sebagai suatu proses penerapan gagasan, ide, tujuan, dan keseluruhan program yang termuat di dalam suatu kurikulum. Setiap kurikulum termasuk kurikulum baru memiliki gagasan dan ide yang tercermin dalam tujuan, program, dan pendekatan dalam proses pembelajaran maupun dalam sistem evaluasinya. ${ }^{25}$

Dalam mengimplementasikan kurikulum, guru pendidikan agama Islam di SMP Muhammadiyah 1 Depok telah mempersiapkan diri dengan sebaik-baiknya. Hal ini tercermin dari pemahaman guru secara seksama terhadap kurikulum, karena telah mengikuti bimbingan teknis atau sosialisasi yang diadakan oleh Dinas Pendidikan Sleman, Dikdasmen maupun sekolah tentang implementasi kurikulum. ${ }^{26}$ Agar implementasi kurikulum dapat berhasil seperti yang diharapkan oleh pemerintah dan memenuhi harapan masyarakat, maka implementasi kurikulum harus mencakup tiga aspek, yaitu sebagai berikut.

\section{Perencanaan}

Sebelum melaksanakan proses pembelajaran, guru pendidikan agama Islam di SMP Muhammadiyah 1 Depok telah melakukan persiapan dengan membuat perangkat pembelajaran, seperti silabus dan RPP. RPP yang dijabarkan dari silabus, di reka sedemikian rupa sehingga dapat menunjang terlaksananya proses pembelajaran yang baik. ${ }^{27}$ Hal ini terlihat dari hasil dokumentasi RPP yang telah dibuat oleh guru dengan rincian memuat alokasi waktu, KI, KD dan Indikator,

25 Deitje Adolfien Katuuk, "Manajemen Implementasi Kurikulum", dalam Jurnal Cakrawala Pendidikan, Vol. XXXIII, No. 1, 2014, hlm. 16.

${ }^{26}$ Wawancara dengan Nurul Cholidiyah, (Guru ISMUBA SMP Muhammadiyah 1 Depok), Mei 2018.

27 Wawancara dengan Nurul Cholidiyah, (Guru ISMUBA SMP Muhammadiyah 1 Depok), Mei 2018. 
Tujuan Pembelajaran, Materi Pembelajaran, Metode Pembelajaran, Media dan Bahan, Sumber Belajar, Langkah-langkah pembelajaran dan penilaian. ${ }^{28}$

Telaah terhadap literatur di atas menunjukkan bahwa implementasi kurikulum pada aspek perencanaan memperlihatkan guru pendidikan agama Islam di SMP Muhammadiyah 1 Depok mempersiapkan diri sebaik mungkin untuk melakukan proses pendidikan. Hal ini terlihat dari perangkat pembelajaran seperti silabus dan rpp yang mengacu kepada KI dan KD yang telah dibuat oleh guru pendidikan agama Islam.

\section{Pelaksanaan}

Implementasi kurikulum pendidikan agama Islam di SMP Muhammadiyah 1 Depok dilakukan untuk mewujudkan tercapainya tujuan pendidikan nasional dan pendidikan kemuhammadiyahan, yaitu membentuk manusia muslim yang beriman, bertaqwa, berakhlak mulia, cakap, percaya pada diri sendiri, berdisiplin, bertanggung jawab, cinta tanah air, memajukan dan mengembangkan ilmu pengetahuan dan keterampilan, beramal menuju terwujudnya masyarakat utama, adil dan makmur yang diridhai Allah SWT serta menghasilkan sumber daya manusia yang handal. ${ }^{29}$

Metode yang digunakan adalah every one is a teacher here dan modelling the way, menggunakan media kertas gambar, spidol, laptop dan LCD, menggunakan sumber belajar Departemen Agama, Al Qur'an dan Terjemahnya, Abidin Fuadi Nugroho, 2017. Buku Siswa Mata Pendidikan Aqidah Akhlak SMP/MTs Muhammadiyah Kelas VII. Jakarta: Majelis Pendidikan Dasar dan Menengah Pimpinan Pusat Muhammadiyah dan Yunahar Ilyas, 2002, Kuliah Aqidah Islam, Yogyakarta: LPPI UMY. ${ }^{30}$ Berdasarkan hasil dokumentasi tersebut, dapat dipahami bahwa guru menggunakan ragam variasi metode, media dan strategi untuk menciptakan proses belajar yang efektif sehingga tidak berjalan secara monoton.

\section{Penilaian}

Berdasarkan hasil wawancara yang telah dilakukan menunjukkan bahwa penilaian proses pembelajaran di SMP Muhammadiyah 1 Depok dilaksanakan sesuai

\footnotetext{
28 Dokumentasi RPP di SMP Muhammadiyah 1 Depok, Mei 2018.

${ }^{29}$ Dokumentasi buku ISMUBA SMP Muhammadiyah 1 Depok, Mei 2018.

${ }^{30}$ Dokumentasi RPP di SMP Muhammadiyah 1 Depok, Mei 2018.
} 
dengan format penilaian kurikulum yang diterapkan, yaitu meliputi Ulangan Harian, Ujian Tengah Semester, Ujian Akhir Semester, Tugas dan lain sebagainya. Hal ini dilakukan untuk menilai ketiga aspek yang masuk dalam penilaian, yaitu aspek kognitif, afektif dan psikomotor. Jadi, dapat dilihat bahwa evaluasi dilakukan secara sistematis yang dilakukan oleh guru dan satuan pendidikan, yaitu Majelis Dikdasmen. ${ }^{31}$

Implementasi kurikulum pendidikan agama Islam yang dilakukan oleh SMP Muhammadiyah 1 Depok berdasarkan analisi hasil wawancara dipengaruhi oleh beberapa faktor, yaitu: pertama, faktor pendukung, seperti kualitas guru yang baik, peserta didik yang responsif, sarana dan prasarana, dan lain-lain. Kedua, faktor penghambat, seperti input peserta didik yang sebagian besar belum bisa baca tulis Al-qur'an dan diatasi dengan kegiatan Tuntas Baca Tulis Al-qur'an satu semester bagi peserta didik baru, peran orang tua yang masih minim untuk mendukung program sekolah dan diatasi dengan melakukan kegiatan parenting untuk orang tua peserta didik. ${ }^{32}$

Keberhasilan impelemetasi kurikulum diartikan sebagai pencapaian kompetensi yang dirancang dalam dokumen kurikulum oleh seluruh peserta didik. Penilaian hasil belajar dan hasil kurikulum diukur dari pencapaian kompetensi. Kompetensi untuk Kurikulum 2013 dirancang, yaitu:

a. Isi atau konten kurikulum yaitu kompetensi dinyatakan dalam bentuk Kompetensi Inti (KI) kelas dan dirinci lebih lanjut dalam Kompetensi Dasar (KD) mata pelajaran.

b. Kompetensi Inti (KI) merupakan gambaran secara kategorial mengenai kompetensi dalam aspek sikap, pengetahuan, dan ketrampilan (kognitif dan psikomotor) yang harus dipelajari peserta didik untuk suatu jenjang sekolah, kelas dan mata pelajaran. Kompetensi Inti adalah kualitas yang harus dimiliki seorang peserta didik untuk setiap kelas melalui pembelajaran KD yang diorganisasikan dalam proses pembelajaran peserta didik aktif.

\footnotetext{
31 Wawancara dengan Nurjanah, (Guru ISMUBA SMP Muhammadiyah 1 Depok), Mei 2018.

32 Wawancara dengan Siska Yulianti, (Guru ISMUBA SMP Muhammadiyah 1 Depok), Mei 2018.
} 
c. Kompetensi Dasar (KD) merupakan kompetensi yang dipelajari peserta didik untuk mata pelajaran di level tertentu.

d. Kompetensi Inti dan Kompetensi Dasar di jenjang pendidikan menengah diutamakan pada ranah sikap sedangkan pada jenjang pendidikan menengah ke atas pada kemampuan intelektual (kemampuan kognitif tinggi).

e. Kompetensi Inti menjadi unsur organisatoris (organizing elements) Kompetensi Dasar yaitu semua KD dan proses pembelajaran dikembangkan untuk mencapai kompetensi dalam Kompetensi Inti.

f. Kompetensi Dasar yang dikembangkan didasarkan pada prinsip akumulatif, saling memperkuat (reinforced) dan memperkaya (enriched) antar mata pelajaran dan jenjang pendidikan (organisasi horizontal dan vertikal).

g. Silabus dikembangkan sebagai rancangan belajar untuk satu tema (SD/MI) atau satu kelas dan satu mata pelajaran (SMP/MTS, SMA/MA, SMK/MAK). Dalam silabus tercantum seluruh KD untuk tema atau mata pelajaran di kelas tersebut.

h. Rencana Pelaksanaan Pembelajaran dikembangkan dari setiap KD yang untuk mata pelajaran dan kelas tersebut. ${ }^{33}$

Untuk meminimalisir berbagai faktor penghambat yang mempengaruhi pengembangan dan implementasi kurikulum, maka terdapat dua sumber daya yang harus menjadi perhatian dalam implementasi kurikulum, yaitu sumber daya utama dan sumber daya pendukung. Sumber daya utama terdiri atas sumber daya manusia dan bahan ajar. Guru adalah faktor utama yang akan mengimplementasikan kurikulum. Berkaitan dengan hal tersebut, seorang guru perlu mempersiapkan halhal, yaitu:

a. Kompetensi dan sikap.

b. Pelibatan guru-guru dalam prose pengembambilan keputusan implementasi kurikulum.

c. Perlu dibangun dan dipersiapkan hubungan kolegial yang berkualitas di sekolah-sekolah. 


\section{d. Melibatkan orang tua dalam implementasi.}

Sementara itu, penguatan sumber daya pendukung, terutama ketersediaan sarana yang mendukung fasilitas pembelajaran, yaitu buku sebagai bahan ajar. Pemerintah telah menyiapkan buku pelajaran terutama buku pelajaran untuk sekolah dasar (SD). Buku pelajaran untuk semua tema pelajaran sudah dipersiapkan. Di samping itu, telah dipersiapkan pula buku pedoman bagi guru-guru. Penyiapan buku bahan ajar hendaknya tetap memerhatikan prinsip-prinsip relevansi dengan kehidupan anak. Buku hendaknya dirancang untuk dapat mendorong inspirasi guru dalam mengembangkan bahan ajar yang relevan dengan menghubungkan lingkungan terdekat sebagai sumber belajar. ${ }^{34}$

\section{E. KESIMPULAN}

Pengembangan kurikulum pendidikan agama Islam di SMP Muhammadiyah 1 Depok (MUSADE) menggunakan dasar yang dijadikan sebagai acuan dalam pengembangannya, yaitu mengacu kepada Kurikulum Kemendikbud dan Kurikulum dari Majelis Pendidikan Dasar dan Menengah (Dikdasmen). SMP Muhammadiyah 1 Depok dalam mengembangkan kurikulum pendidikan agama Islam telah sesuai dengan langkah-langkah pengembangannya dan telah melibatkan berbagai pihak dalam proses pengembangan kurikulum, yaitu Guru, Komite Sekolah, Masyarakat dan Majelis Dikdasmen (Pendidikan Dasar dan Menengah), meskipun dalam pengembangannya masih ditemukan hambatan-hambatan. Adapun aspek yang dikembangkan, yaitu struktur kurikulum, standar kompetensi lulusan, standar isi, standar proses dan standar penilaian.

Sementara itu, implementasi kurikulum di SMP Muhammadiyah 1 Depok bisa dilihat dari guru pendidikan agama Islam yang telah mempersiapkan diri dengan sebaik-baiknya. Hal ini tercermin dari pemahaman guru secara seksama terhadap kurikulum, karena telah mengikuti bimbingan teknis atau sosialisasi yang diadakan oleh Dinas Pendidikan Sleman, Dikdasmen maupun sekolah tentang implementasi kurikulum. Dalam implementasi kurikulum, agar dapat berhasil seperti yang diharapkan oleh pemerintah dan memenuhi harapan masyarakat, maka implementasi kurikulum pendidikan agama Islam di SMP Muhammadiyah 1 Depok 
telah mengacu kepada tiga aspek, yaitu perencanaan proses pembelajaran, pelaksanaan proses pembelajaran dan penilaian proses pembelajaran, meskipun dalam implementasinya masih ditemukan hambatan-hambatan.

\section{DAFTAR PUSTAKA}

Bahri, Syamsul, "Pengembangan Kurikulum Dasar dan Tujuannya", dalam Jurnal Ilmiah Islam Futura, Vol. XI, No. 1, 2011.

Depdiknas, Undang-Undang Nomor 20 Tahun 2003 Tentang Sistem Pendidikan Nasional, Jakarta: Depdiknas, 2003.

Fitroh, "Pengembangan Kurikulum Berbasis Kompetensi dan Strategi Pencapaian", dalam Studi Informatika: Jurnal Sistem Informasi, Vol. 4, No. 2, 2011.

Gunawan, Heri, Kurikulum dan Pembelajaran Pendidikan Agama Islam, Bandung: Alfabeta, 2013.

Hamalik, Oemar, Dasar-Dasar Pengembangan Kurikulum, Bandung: Remaja Rosdakarya, 2008.

Idi, Abdullah, Pengembangan Kurikulum dan Praktik, Yogyakarta: Ar-Ruzz Media, 2007.

Ismail, Lukman \& Risfaisal, "Eksistensi Gerakan Muhammadiyah dalam Pendidikan di Era Modernisasi", dalam Jurnal Equilibrium Pendidikan Sosiologi, Vol. V, No. 2, 2017.

Jahya, Yudrik, Pandangan Pelaksanaan Kurikulum Raudhatul Athfal, Jakarta: Departemen Agama RI, 2005.

Katuuk, Deitje Adolfien, "Manajemen Implementasi Kurikulum", dalam Jurnal Cakrawala Pendidikan, Vol. XXXIII, No. 1, 2014.

Khasanah, Siti Zulfatun, \& Zainal Arifin, "Implementasi Pengembangan Kurikulum di SMP Muhammadiyah Boarding School (MBS) Yogyakarta", dalam Tadris: Jurnal Pendidikan Islam, Vol. 12, No. 1, 2017.

Kunandar, Guru Profesional Implementasi Kurikulum Tingkat Satuan Pendidikan (KTSP) dan Sukses dalam Sertifikasi Guru, Jakarta: Raja Grafindo Persada, 2007.

Majelis Dikdasmen Kurikulum Pendidikan Al-Islam, Kemuhammadiyahan dan Bahasa Arab, Jakarta: Pimpinan Pusat Muhammadiyah, 2017.

Mansur \& Mahfud Junaidi, Rekonstruksi Sejarah Pendidikan Islam di Indonesia, Jakarta: Departemen Agama RI, 2005.

Mansur, Rosichin, "Pengembangan Kurikulum Pendidikan Agama Islam Multikultural", dalam Jurnal Kependidikan dan Keislaman FAI Unismea, Vol. 10, No. 2, 2016.

MOF, Yahya, "Manajemen Implementasi Kurikulum dan Proses Pembelajaran", dalam Jurnal Tarbiyah Islamiyah, Vol. 5, No. 2, 2015. 
Muhaimin, Pengembangan Kurikulum Pendidikan Agama Islam di Sekolah, Jakarta: Raja Grafindo Persada, 2007.

Sagala, Syaiful, "Pengembangan dan Implementasi Kurikulum Penting Untuk Meningkatkan Kualitas Pembelajaran", dalam Digital Repository Universitas Negeri Medan, 2016.

Shofiyah, "Prinsip-Prinsip Pengembangan Kurikulum dalam Upaya Meningkatkan Kualitas Pembelajaran", dalam Edureligia: Jurnal Pendidikan Agama Islam, Vol. 2, No. 2, 2018.

Sukmadinata, Nana Syaodih, Pengembangan Kurikulum Teori dan Praktik, Bandung: Remaja Rosdakarya, 2013.

Suyatmini, “Implementasi Kurikulum 2013 pada Pelaksanaan Pembelajaran Akuntansi di Sekolah Menengah Kejuruan", dalam Jurnal Pendidikan Ilmu Sosial, Vol. 27, No. 1, 2017. 